\title{
The credibility of monetary policy and the fiscal response to the pandemic in the Eurozone
}

\author{
Pompeo Della Posta ${ }^{1} \cdot$ Mario Morroni ${ }^{2}$ (D)
}

Received: 23 March 2021 / Accepted: 9 October 2021 / Published online: 1 February 2022

(c) Japan Association for Evolutionary Economics 2022

\begin{abstract}
The novel nature of the economic and social crisis, due to the spread of COVID-19, requires new rules and a drastic change in the economic measures to be adopted. The pandemic has caused a spiral of supply-demand shocks that brings about several market failures that make necessary a public intervention to assure the return to health security in the first place and then to restore economic growth and reduce unemployment. Fiscal policy has to intervene both to cover health expenses and sustain families' income and firms' fixed costs, and to create the basis for a future recovery through investment. To guarantee the stability of the resulting higher public debt, expansionary monetary policies have been implemented even in a nonconventional way. In the euro area, among other measures, a pandemic emergency purchase programme (PEPP) has been adopted, through which the European Central Bank (ECB) has been buying temporarily existing public debt on the secondary market. We ask whether the ECB should go even further monetising permanently on the primary markets the public debt of euro area countries or relieving a fraction of the debt that they are currently holding. An alternative possibility would be the issuance of perpetual bonds to be bought by the central bank. Needless to say, such measures are rather controversial, not only considering their political feasibility, but also for the feared effects on the central bank's anti-inflationary credibility and on moral hazard. We argue that a sufficiently strong political will might help overcoming the objection regarding feasibility. Central bank's anti-inflationary credibility may not necessarily be a concern: according to the credibility theory, in the case of unexpected shocks, no credibility can be gained by following policies that are not credible themselves. On the other hand, moral hazard cannot be an issue when a given measure is fully justified by the occurrence of extraordinary circumstances. Finally, we show that when the economy is hit by a stochastic shock, a moderate
\end{abstract}

\footnotetext{
Early versions of this papers were presented by the authors at the Annual Conference of the Italian Association of Economics (SIE), 22 October 2020, and at the Annual Conference of the Italian Association for the History of Political Economy (STOREP), 17-18 June 2021. We would like to thank the participants to these conferences for interesting discussion and two anonymous referees for their suggestions that have helped us to better clarify some relevant aspects of our article.
}

Extended author information available on the last page of the article 
inflation might well be optimal, as it would allow a reduction of the unemployment rate.

Keywords COVID-19 · Pandemic · Uncertainty · Fiscal policy · Monetary policy credibility $\cdot$ Optimum currency areas $\cdot$ Inflation $\cdot$ Fiscal multipliers

JEL Classification E3 $\cdot$ E4 $\cdot$ E5 $\cdot$ E6 $\cdot$ F4

\section{Introduction}

The COVID-19 pandemic is not a repetition of past shocks on supply or on demand, since it has entailed transitory freezing of the economy. The economic and social crisis triggered by the spread of the virus is characterised by negative externalities, asymmetric information and uncertainty. This makes private contracting ineffective: the market action fails, and public intervention is necessary by means of both fiscal and monetary non-conventional new policies.

In the short run, fiscal policy must sustain health expenses, families' income and firms' fixed costs (to avoid bankruptcies and hold workers). In addition, to create the basis for a future recovery, it is necessary to implement an exceptional plan of public investment whose fiscal multiplier should be much greater than one. Investment should be concentrated on the green transition, digital technology (as also suggested, in the European Union, by the European Commission) and on labour-intensive activities, such as education and research. Additional public debt, then, will have to be created. To guarantee its stability, expansionary monetary policies have been implemented, also in a non-conventional way, especially when the zero-lower bound on interest rates had already been reached. In the European Economic and Monetary Union (EMU), among other measures, a pandemic emergency purchase programme (PEPP) has been adopted, through which the European Central Bank has been buying temporarily existing public debt on the secondary market. As long as there is no effect on prices, such measures should find no objections.

Should the European Central Bank go even further? Should the public debt of euro area countries be permanently 'monetised' by the central bank on the primary markets, to avoid its further growth and unsustainability? Or, even, should a measure of debt relief on the debt created to respond to the pandemic be implemented? Or, alternatively, should perpetual bonds be issued? Assuming that a consensus could be reached to modify the rules of the Maastricht Treaty that define the operational boundaries of the European Central Bank, would such measures hamper its anti-inflationary credibility and induce moral hazard on the potential beneficiaries? These are the questions that we are addressing in this paper and to which, in our view, a correct interpretation of economic theory allows to give the appropriate answers.

This article is organized as follows: Section 2 reports briefly the most important issues raised by the spreading of the pandemic and the responses that they would require. Section 3 analyses the implications of the issuance of perpetual bonds. 
Section 4 discusses credibility theory and the conclusions reached in a deterministic context as opposed to a more realistic stochastic one. Section 5 shows that the conclusions reached by the optimum currency area theory are fully consistent with credibility theory, when correctly interpreted in its stochastic version. Section 6 applies the theoretical conclusions derived from credibility theory to the European Central Bank, to conclude that an even more active role would not imply a loss of credibility. Section 7 contains some concluding remarks. The appendix proposes a simple credibility model, showing that even if the European Central Bank intervention were to produce a moderate inflation, this might well be optimal-provided that antiinflationary preferences are not too high-since it would allow to reduce the unemployment rate that would result otherwise from a non-countered shock.

\section{The response to the pandemic stochastic shock}

The spread of COVID-19, which is destroying people's lives, jobs and businesses, is characterised by supply and demand shocks, externalities, information asymmetries and uncertainty about the effects of the evolution of the pandemic.

The transitory lockdown periods imposed by authorities have hampered the economies. Most countries have experimented a self-fulfilling spiral of demand-supply shocks. ${ }^{1}$ Stoppages of the production of some intermediate goods, components and raw materials have caused blockages in many supply chains. On the other hand, the reduction of people mobility and the increase in the unemployment rate have caused a sharp decrease in consumers' demand of many commodities. As a consequence, facing these new, specific features of the current crisis, policy makers cannot repeat the past policies implemented in response to the great recession blasted in 2008, but they have to implement a new set of measures that increase health security in the first place and boost economic growth.

The pandemic brings about externalities on health and on the economy. Externalities on health conditions are due to the very high transmission rate, while externalities on the economy stem from the interruption of supply chains.

Information asymmetries depend on the fact that, due to the high number of asymptomatic positive persons, people have difficulty knowing their own health conditions, and the health conditions of people whom they meet.

The World Uncertainty Index reached unprecedented levels at the beginning of the pandemic and remains elevated (Ahir et al. 2021). Radical uncertainty about the future has surged because most individuals are not able to foresee the effects of their actions on the spread of the pandemic and on public health. They are also unable to forecast the duration of the pandemic and its effects on the economy. Moreover, pandemic is entailing uncertainty on the ability of pharmaceutical industry to produce effective drugs and vaccines in time and quantity required, with affordable costs. Uncertainty causes high transaction costs.

\footnotetext{
${ }^{1}$ On supply shocks that trigger changes in aggregate demand larger than the shocks themselves, see Guerrieri et al. (2020).
} 
In the presence of information asymmetries, uncertainty, high transaction costs ${ }^{2}$ and externalities, which involve a high number of people as in the case of a pandemic shock, it is impossible to reach an agreement with mutual benefit between two private parties that bargain between themselves. Markets are ill-suited to manage such situations because private contracting is ineffective or cannot happen (holdup phenomenon). As a consequence, the market action fails, and state intervention is necessary.

In the short run, fiscal policy must sustain the health system, financing research on new vaccines and drugs that are able to stop the spread of the pandemic and support hospitals and primary care centres. Short run actions must be taken also to help education systems in coping with online didactics, as well as to sustain family incomes and the revenue of the firms hit by the lockdown, to prevent bankruptcies and to finance retention of workers to ensure a quick restart when the time comes. These policies have also to fight the negative consequences of the rapid structural transformation due to the decline of activities involving close human contact and to the expansion of non-human-contact sectors that are less labour intensive (Stiglitz 2020). In particular, necessary measures include: providing resources to the health systems, temporary unemployment benefits to all workers who will be losing their jobs and financial assistance to firms that have to cease or reduce their production; financing the education system to implement distance learning. ${ }^{3}$

These short period policies, albeit necessary, have a low fiscal multiplier with scant effect on GDP growth. In addition to these necessary short run measures, a well-directed and highly stimulative public spending is required to create the basis for a future recovery. To this end, it is necessary to implement public spending with a fiscal multiplier much greater than one. A large review of over a hundred studies on the fiscal multiplier shows that there is a large observed variance in the estimates. However, in most studies the public investment multiplier varies from 1 to 2.5, while the multipliers of tax reliefs and transfers to the private sector vary between 0 and 0.5 (Asatryan et al. 2020). Fiscal multipliers do not apply when the economy is stopped due to a period of lockdown. However, as soon as there is a return to health security, and administrative restrictions on people mobility are withdrawn, public spending will have a positive effect on GDP and employment growth, thanks to the fiscal multiplier action. IMF recent applied studies have shown that the fiscal multiplier does not stay constant over time but varies according to the state of the

\footnotetext{
${ }^{2}$ Coase (1960); Stiglitz (1989, pp. 36-37); Medema (2009 in 2011, Chap. 5, 6, 7). Coase hoped to convince economists to abandon the assumption of zero transaction costs. He writes that: "The world of zero transaction costs has often been described as a Coasian world. Nothing could be further from the truth" (Coase, 1988, pp. 157, 174).

3 See in Assenza et al. (2020) the "Open letter of European economists to the presidents of the European Union institutions and to the heads of state and government of the member countries. European Renaissance bonds to face Europe's health and economic emergency". This open letter, which was signed by more than 1,850 European economists from about 550 Universities, was promoted by Tiziana Assenza, Andrea Boitani, Sheila Chapman, Nicos Christodoukakis, Fabrice Collard, Paul De Grauwe, Pompeo Della Posta, Michele Grillo, Jens Hölscher, Klaus Kempf, Jackie Krafft, Luisa Lambertini, Enrico Marelli, Mario Morroni, Marcello Signorelli, Roberto Tamborini, Hans-Michael Trautwein, Amy Verdun, Hans-Jürgen Wagener.
} 
economy. The multiplier is lower in phases of economic expansion and higher in slowdowns. ${ }^{4}$ As a consequence, when the health crisis is overcome and the economy starts to recover, but it is still depressed with an actual GDP much lower than potential GDP, the fiscal multiplier could have an important role in helping economies to exit from the pandemic crisis and to return to previous levels of GDP and employment.

There is an increasing consensus among economists on the fact that the novel nature of the COVID crisis requires completely different instruments of economic policy with a radical change from the prevalent approach adopted in the last decade. The focus on the increasing public debts, that was central during the great recession blasted in 2008, appears less important. In contrast, more attention is now paid to the rate of inflation and private debt. Tackling the economic consequence of the pandemic, the focus is on exceptional structural plans to foster the economic recovery through measures with long-lasting effects that push long-term public investment to be concentrated on the green transition, digital economy and on labour-intensive activities, such as education and research (Gaspar et al. 2020). This plan has to be supported by an expansionary monetary policy.

The pandemic is creating rapidly rising inequality. "Because machines cannot be infected by the virus, they will look relatively more attractive to employers, particularly in the contracting sectors that use relatively more unskilled labor." (Stiglitz 2020). A redistributive economic policy is needed by applying tax progressivity and higher taxes to highly profitable companies, to large estate properties, and to capital movements and financial transactions. As pointed out in a recent article published by IMF's researchers, "[t]he ensuing revenues would help pay for critical services, such as health and social safety nets, during a crisis that has disproportionately hurt the poorer segment of society" (Gaspar et al. 2020). Moreover, a redistributive policy has an expansionary effect on GDP thanks to the fact that the marginal propensity to consume of low-income people is higher than the marginal propensity to consume of a higher income people.

Needless to say, the required fiscal effort in the context of a depressed economy can only be made possible thanks to the accumulation of public debt. This is what we are going to discuss in the next section.

\section{How to pay for the COVID-19 pandemic: perpetual bonds and debt relief}

President Joe Biden's Administration adopted a COVID-19 relief plan for an additional \$1.9 trillion of fiscal spending. The European Commission decided the deactivation of the Fiscal Compact until 2022, allowing Eurozone countries to increase their balance deficit. The European Parliament, the European Commission and the European Group have introduced a plan called Next Generation EU for an amount

\footnotetext{
${ }^{4}$ Blanchard O, Leigh D (2013, May 3; 2013); cfr. Morroni (2018, pp. 51-52).
} 
of $€ 1.8$ billion ( $\$ 2.2$ billion) together with a set of measures to cope with an unprecedented crisis that is a threat to people in all countries.

To face the economic and health crisis, all countries have planned a strong fiscal stimulus by a means of direct expenditure and tax cuts. The fiscal expansionary measures amounted to: $15 \%$ of GDP in the US, about $21 \%$ of GDP in Japan, about $14 \%$ of GDP in Germany, 5\% of GDP in Italy and only 3.2\% of GDP in Spain (Stirati 2020).

The risk is that high debt burdens and tight financing constraints could hamper the fiscal policy response to the COVID-19 health and economic crisis. To face an increasing public debt, the danger is to apply again fixed rules that imply restrictive fiscal policies, as happened in the Eurozone during the 2010-2012 crisis of the sovereign debts. ${ }^{5}$ Austerity policies were self-defeating, because the ratio of public debt to gross domestic product perversely increased, due to their larger contractionary effect on the denominator. The reason is quite straightforward: if the fiscal multiplier is larger than 1, which is quite reasonable especially during a crisis, then a fiscal contraction (that would reduce public debt) also reduces the GDP more than proportionally. As a result, the public debt-to-GDP ratio increases since the denominator decreases more than what the numerator does. ${ }^{6}$

To guarantee the sustainability of the debt, avoiding a remake of the 2010-2012 sovereign debt crises on an immeasurable larger scale, the nominal interest rate on the stock of public debt should be lower than the growth rate of nominal GDP. It is worth mentioning an interesting proposal that aims at assuring the sustainability of the increase of public debts, removing constraints on single countries' ability to fight the pandemic and its economic consequence: the issuance of perpetual bonds, or consols.

Perpetual bonds are the longest term debt possible because the principal never has to be repaid, only an interest is payable with an annual fixed coupon. In the case of a perpetual bond issued by the European Union, the payment of interest would burden the funds of the European budget. According to George Soros, with an interest rate of $0.5 \%$, an amount of $€ 1000$ billion of perpetual bonds implies the payment of $€ 5$ billion per year, namely $3 \%$ of the European budget. To maintain an AAA rating, the European Union must cover this cost of servicing the bonds by taxes that, as envisaged by George Soros, have only to be authorised, without the need to be implemented. This makes the process faster, because "imposing taxes is

\footnotetext{
${ }^{5}$ Here, we refer to the Fiscal Compact in the Treaty on Stability, Coordination and Governance in the Economic and Monetary Union (TSCG) (January 2013). According to the Fiscal Compact, public deficit must not exceed the 0.5 per cent of GDP for states with a debt-to-GDP ratio exceeding 60 per cent. It is a strengthening of the budget-discipline rules contained in the 1997 Stability and Growth Pact that establishes automatic sanctions for countries that violated the Maastricht Treaty parameters of the 3 per cent deficit to GDP ratio and of the 60 per cent of the debt to GDP.

6 International Monetary Fund (IMF) (2012); Batini et al. (2012); Coenen et al. (2012); Office for Budget Responsibility (2012); Blanchard and Leigh (2013a, ba, b; 2013a, ba, b, May 3); Blyth (2013 in 2015, p. 215); Marelli and Signorelli (2017, pp. 71-74); Boitani and Perdichizzi (2018); Morroni (2018, pp. 51-53); Deleidi et al. (2020).
} 
a long drawn out process" (Soros 2020). ${ }^{7}$ In case perpetual bonds are bought by the European Central Bank, the interest paid to it would be transferred back to the central banks-and in turn to the governments-of the Eurozone countries.

Corsetti et al. (2020) have cast doubts on the effectiveness of perpetual bonds, because they forecast that the interest cost of a consol would be much higher than $0.5 \%$, hypothesized by Soros, and could set in the range of $2.0 \%$ and $3 \%$. They maintain that "[t]he cheapest way to finance the European Recovery Fund would be to issue joint EU debt at shorter maturities, then pass those low interest rates onto member states through loans at low margins over funding costs and with very long maturities. Supporting member states through low rates and maturity transformation would further reinforce debt sustainability across all member states."

An alternative proposal is the one put forward by Becchetti (2020) and Becchetti and Scaramozzino (2021), and in an appeal published on February 5, 2021 in 10 European newspapers and signed by about 100 European economists (Dufrêne et al. 2021). The appeal urged the European Central Bank to cancel the public debt originating from the pandemic and appearing in the assets side of its balance sheet precisely with the objective of avoiding that the burden of the debt might prevent or might make extremely hard the economic recovery of European countries after the pandemic. The underwriters of this appeal observe that, after all, this is what happened in the case of the German public debt. Two thirds of the German public debt was cancelled in 1953, allowing the full recovery of that country in the years that followed. Reinhart and Trebesch (2016) provide an account of the many cases of public debt relief in the past and argue that write-offs have been generally followed by higher economic growth or improved credit ratings, while this has not been the case in the presence of milder forms of debt relief, such as debt restructuring (implying a longer debt maturity) and interest rate reductions. Kumhof et al. (2020) also argue that since central bank money cannot be interpreted anymore as a liability, as it was the case under the gold standard regimes of the past, provided that monetary institutions are credible and that there is a significant demand for it, printing money on a large scale (as it might be the case to stabilize public debt) would not have any inflationary consequences nor undermine central bank's anti-inflationary reputation.

However, in spite of all this and in spite of the declaration of the president of the European Parliament, Davide Sassoli, who argued that cancelling the governments' debt originated in response to the COVID-19 pandemic would be "an interesting working hypothesis" (CDE, News 2020), the President of the European Central Bank, Christine Lagarde rejected firmly such a possibility, on the grounds that debt forgiveness would go against the prescriptions of the Maastricht Treaty (Reuters Staff 2020).

\footnotetext{
${ }^{7}$ Soros (2020). Perpetual bonds have been recently backed also by other authors, among them see: Garicano (2020); Giavazzi and Tabellini (2020). Cf. the collection of papers in Baldwin and Weder di Mauro (eds) (2020a, b). Soros (2020) is very critical of Eurobonds because they imply a degree of mutualisation that is not accepted by many Eurozone countries. According to Soros, perpetual bonds have instead the advantage that they imply only the payment of the annual interest rate, which is negligible and could be easily accepted.

${ }^{8}$ Corsetti et al. (2020, p. 227). On this, see also Erce et al. (2020).
} 


\section{Monetisation of public debt and monetary policy credibility ${ }^{9}$}

Many economists of different orientations suggest that the debt created to cope with the needs resulting from the COVID-19 should be 'monetised', for example with the central banks buying it on the primary markets with the creation of new money. ${ }^{10}$ The main objections to such direct-money financing of public expenditure in the European economic and monetary union (hereafter EMU) relate: firstly, to its institutional feasibility, given the requirements of the Treaty on the Functioning of the European Union; and, secondly, to the negative effects that the monetisation would supposedly have on the anti-inflationary European Central Bank's credibility to control inflation.

The first objection could be overtaken by political will. As for the second point, it is worth recalling the evolution of the theory of 'credibility'. The first generation of credibility theory, dating back to the 1970 s and $1980 \mathrm{~s},{ }^{11}$ contended that central banks should follow monetary rules rather than exercise discretion. It was asserted that, in case of a discretional behaviour, the 'rational expectations' of economic actors would anticipate the central bank's 'time inconsistency' problem, namely its policy that reneges on the initial promise not to run a monetary expansion in the supposedly vain attempt to increase production and decrease unemployment.

It was contended that, in case of an injection of money by the central bank, the expectation of inflation would pre-emptively become a self-fulfilling prophecy, leaving no real effect on unemployment and production, which would remain unchanged, anchored to previous levels. Therefore, the problem of the 'time inconsistency' of the central banks would be solved by tying their hands, imposing strict rules on them.

This initial version of credibility theory was based on the rational expectations theory that was linked to the unlimited confidence in self-regulating markets, without any concern about unemployment.

Credibility theory became the theoretical basis justifying the adhesion to a fixed exchange rate system, with the creation of the European Monetary System (hereafter EMS) at the end of 1979. A fixed exchange rate and monetary rule should have enhanced anti-inflationary credibility, curbed inflationary expectations and reduced instability. Devaluing the domestic currency, instead, would have implied a deviation from the fixed exchange rate rule and for this reason, it had to be avoided, in the hope of not losing credibility.

Credibility theory has represented the justification for the European Central Bank's institutional architecture, set up with the objective of preserving its antiinflationary credibility. In the view of early credibility theory, since monetary independence produced only an inflationary bias without any substantive benefit, giving

\footnotetext{
9 This section draws in part from Della Posta (2020).

10 See, for instance, Blanchard and Pisani-Ferry (2020), Giavazzi and Tabellini (2020, Galì (2020), De Grauwe (2020).

11 This theory has been developed, in particular, by the contributions of Kydland and Prescott (1977) and Barro and Gordon (2020).
} 
it up by tying the hands of policy makers by means of joining a currency or a monetary union would always be optimal, because it would avoid running the risk of inflation. The European Central Bank was created along the lines of the Bundesbank. Therefore, the European Central Bank is a sort of continental Bundesbank. ${ }^{12}$

\section{Optimum currency areas and the stochastic approach: the second generation of credibility theory}

The original credibility theory, regarding a monetary union as a means to hamper devaluation policies, conflicted strongly with the parallel stream of literature on optimum currency areas (hereafter OCA) that examined the conditions to be met for a currency or monetary union, in which exchange rate and monetary independence were renounced, to be optimal. It did so by asking:

- how likely an asymmetric shock affecting a country would be, according to Kenen's product-diversification criterion;

- how easily the shock could be absorbed by automatic market mechanisms, according to Mundell's criterion on mobility and flexibility of labour and capital, so that they can move to areas with a higher demand for labour and capital;

- and how effective the forsworn exchange rate instrument might have been, according to McKinnon's criterion on the degree of openness.

The OCA theory concluded, then, that if a country was likely to be hit by an asymmetric shock, and if, that being the case, no automatic mechanism based on factors' mobility would guarantee the return to a satisfactory equilibrium, giving up the possibility of an effective exchange rate devaluation would not be optimal.

Within the original credibility theory, which was based on deterministic models, it was impossible to take into account stochastics shocks due to contingency and randomness. This limit was overcome with the second generation of credibility theory that considered the possibility that production is hit by unexpected and asymmetric shocks. This led to the same conclusion as OCA theory: if production is hit by an unexpected and asymmetric shock, one can no longer conclude that rules (whether a domestic or an external tying of hands) are always preferable to discretion.

Moving from a deterministic to a stochastic environment, such that the output or the unemployment rate may be hit by negative shocks, shows that it is not possible to conclude that the imposition of fixed rules to which the central bank has to undergo produces a better result than under discretion; while the 'rule' solution would allow a reduction in the inflationary bias emerging in the discretionary case, it would not allow a response to the negative shocks hitting the real economy. The greater the variability of the shock, the more it would be appropriate not to commit to strict rules. Conversely, it would be best to follow a fixed rule when the shock variance is

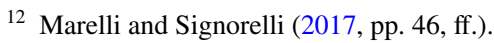


not very high, in which case the benefit of the reduction of the inflationary bias more than compensates for the loss of the possibility to operate counter-cyclically.

The consequences of binding the hands of policy makers in conditions of uncertainty remind us of the situation faced by Ulysses when passing in front of the Sirens. ${ }^{13}$ In Homer's story, the sorceress Circe warns Ulysses to steer clear of the Sirens' island, because the sailors who hear the song of Sirens are bewitched by its sweetness and their ship smashes upon very sharp cliffs, joining the many victims of the Sirens. Circe suggests to Ulysses that he and his crew should use some pieces of beeswax to block their ears to not hear the song of the Sirens. Ulysses, however, want to hear it and orders his crew to bind him to the ship's mast. It is easy to understand that if Ulysses' ship is caught in a dangerous sea tempest well before reaching the Sirens, with the commander tied to the mast of the boat, and his sailors unable to listen to his orders, the situation would be particularly unfortunate! (Della Posta, 2018).

The rules, therefore, should not be fixed, but rather depend on the specific economic conditions resulting, for example, from the occurrence of a stochastic shock, namely they should be state-contingent (Svensson 1993; Rodrik 2017).

When economic conditions suddenly change, policymakers cannot gain credibility by following policies that are not credible. Drazen and Masson (1994) contributed to the debate by introducing the distinction between "credibility of policies" and "credibility of policymakers". Their main idea is that policymakers cannot gain any anti-inflationary credibility when the policies that they are operating are not sustainable and, therefore, not credible. When a negative shock hits the economy and no exchange rate devaluation takes place, the persistence of the negative effects of the unabsorbed shock is the key element in determining the future lower credibility of the policymaker.

In adhering to a fixed exchange rate rule, a central bank may enjoy an anti-inflationary credibility effect, but it cannot ignore the actual state of the economic fundamentals and/or the negative shocks hitting the economy. The example of Italian devaluation in 1992 is a case in point. Italy had accumulated a large loss of competitiveness over the years 1987-1992. Facing such a declining trend of competitiveness, a devaluation of the exchange rate might have been the only optimal action to take. Policy makers cannot gain any credibility, if the policies that they follow are not sustainable in the longer run and are, therefore, not credible. The late Carlo Azeglio Ciampi, who served as Governor of the Bank of Italy from 1979 to 1993 and as President of the Italian Republic from 1999 to 2006, expressed well the idea of a trade-off implied by the credibility game by comparing the EMS to a rope: you can use it to take yourself out of a well, but also to hang yourself... ${ }^{14}$ With a constant decrease in competitiveness of Italian exports, how could the Italian central bank gain credibility and an anti-inflationary reputation by following a fixed rule of exchange rate stability that damaged the Italian economy?

\footnotetext{
13 Della Posta (2018).

14 This is what Argentina also did when committing to the fixed exchange rate against the US dollar and keeping the commitment in spite of the resulting real exchange rate appreciation.
} 


\section{The pandemic shock and European Central Bank credibility}

Let us consider now the credibility issue in relation to the current crisis due to the spread of COVID-19. The stochastic nature of the shock has been recognized and (almost) everybody has raised issues of credibility of economic policies. The pandemic has made clear to (almost) everybody that the fiscal instrument had to be used to respond to the huge demand and supply shocks hitting the economies of all countries. As we have observed, this entails increasing public debts.

Because of mutual mistrust in the euro area, there is the fear that the expectation of debt monetisation would induce irresponsible, 'free riding' behaviour. Such fear is engendered by the incompleteness and fragmentation of economic and monetary union.

A second element of weakness stems from the fact that, as Soros (2020) remarks, the European Union "is based on the rule of law and the wheels of justice turn proverbially slowly. In contrast, the coronavirus moves very fast and in unpredictable ways."

Facing the pandemic stochastic shock, however, how could the ECB lose its antiinflationary credibility if it agreed to buy government bonds on the primary market or if it financed citizens directly by crediting their current account-which would be less costly for the euro area economies than recourse to debt? In fact, the future repayment of these debts would risk jeopardising the economic recovery capacities of the countries in question, which would have to resort to recessionary austerity policies. This is why an even more active role of the ECB would be appropriate and would not imply a loss of the ECB's anti-inflationary credibility. ${ }^{15}$

Moreover, as the simple credibility model proposed in the Appendix A shows, even targeting a higher inflation rate would be optimal, since it would allow reaching a higher welfare level. This would apply given that the cost of a higher inflation rate would be more than offset by the gain in terms of lower unemployment, thanks to the absorption of the negative effects of the shock that a monetary expansion would make possible.

It is argued that the monetization of public debt could create a problem of moral hazard or trigger an inflationary process. In the case of the pandemic, however, the moral hazard problem does not arise, because the debt does not originate from reckless fiscal indiscipline, but from the health crisis that has affected all European countries.

As far as inflation is concerned, the COVID-19 crisis is driving up prices in some asset sectors, notably energy, food, semiconductors and housing. High uncertainty surrounds future price movement. In countries with advanced economies, two scenarios can be envisioned: a self-fulfilling inflation spiral or a temporary increase in prices with a return to the inflation target after a few quarters.

\footnotetext{
15 The European Central Bank started the PEPP (Pandemic Emergency Purchase Programme) on March 18,2020 , immediately after the spreading of the COVID-19, implying the commitment to buy government public debt for an additional amount of $€ 750$ billion.
} 
Input shortages, prolonged supply disruptions, excess savings accumulated during the pandemic lockdown, recovery demand, price readjustments to compensate for business losses incurred during the lockdown periods, monetary accommodation, and the massive and unprecedented fiscal policy support implemented in response to the COVID-19 crisis could cause overheating and could lead to de-anchoring of inflation expectations, resulting in a self-fulfilling inflation spiral (Blanchard 2021).

A second possible scenario consists of headline inflation peaking at $3.6 \%$ in the final months of 2021, returning to trend in 2022. This scenario is based on confidence that policymakers will react quickly if inflation expectations show signs of de-anchoring and on the consideration that advanced economies are characterized by significant unemployment and unutilized productive capacity (IMF, 2021, pp. 45-57).

As long as inflation expectations remain anchored, expansionary monetary policy is essential to revive growth and make the considerable increase in public debt sustainable. This is the monetary policy adopted to date by the Fed, the Bank of England and the Central Bank of Japan. As for the economic policy of the European Union, in the face of a global calamity of the magnitude of COVID-19, it would be a matter of demonstrating that the Union is playing the protective and guaranteeing role that its citizens expect it to play. ${ }^{16}$

\section{Concluding remarks}

The COVID-19 pandemic has caused negative externalities, asymmetric information and uncertainty, thereby determining market failures that have made a fiscal expansion necessary to sustain health expenses, families' income and firms' fixed costs (to hold workers).

An exceptional plan of public investment, mainly to be concentrated on the green transition, digital technology and on labour-intensive activities, such as education and research is also necessary, to create the basis for a future recovery. Additional public debt, then, will have to be created.

To guarantee the stability of existing public debt, expansionary monetary policies have been implemented in a non-conventional way, given that the zero-lower bound on interest rates had already been reached. In the European Union, among other measures (included the fiscal support assured by the Next Generation EU programme, implying the concession to European countries of loans and grants for a total amount of $€ 750$ billion), a pandemic emergency purchase programme (PEPP) has been adopted, through which the European Central Bank has been buying temporarily existing public debt on the secondary market. As long as there is no effect on prices, such measures should find no objections.

Several authors have been encouraging the European Central Bank to go even further, 'monetising' permanently on the primary markets the public debt of euro area countries to avoid its further growth and unsustainability. After all, since in the euro

${ }_{16}$ Della Posta and Morroni (2020, p. 7). See also the debate in Della Posta and Shure (2020, p. 185 ff.). 
area liquidity has already increased with the PEPP, monetizing permanently public debt would avoid the problem resulting from its accumulation, something that might jeopardize the future economic recovery: the need to follow fixed rules on the functioning of the ECB might well imply a strong limitation to the full efficacy of the measures that it undertakes. Other proposals refer to the issuance of perpetual bonds and even to measures of debt relief on the debt created to respond to the pandemic. Assuming that a consensus could be reached to modify the rules of the Maastricht Treaty that define the operational boundaries of the European Central Bank, would such measures hamper anti-inflationary credibility and induce moral hazard on the potential beneficiaries? In this article, we have argued that, a correct interpretation of economic theory allows to give a negative answer to the latest questions.

As a matter of fact, while according to the first generation of credibility theory, strict rules should be imposed on central banks to avoid inflationary expectations and strengthen their anti-inflationary credibility, if the real economy is hit by unexpected shocks, it can no longer be concluded that fixed rules are preferable to discretion. The 'rule' solution would not allow to respond to such shocks and no credibility can be gained by following sub-optimal policies. As for the risk of moral hazard that might be caused by the adoption of a measure of debt relief, we argue that it cannot be an issue when it is fully justified by the occurrence of extraordinary circumstances.

In the simple model proposed in the Appendix, we have also shown that allowing the inflation rate to increase slightly above its initial target might well be optimal, since it would reduce the unemployment rate resulting from a non-countered shock: the old trade-off between inflation rate and unemployment rate resulting from the Phillips curve still applies, in spite of the many authors who considered it as dead long ago.

\section{Appendix A}

\section{Rules vs. Flexibility: the limits of fixed rules in the presence of uncertainty}

This Appendix illustrates a formal simple model that addresses the problem of time inconsistency in a presence of unexpected shocks. The model shows how in a stochastic environment it is no longer possible to make conclusions about the superiority of the rules with respect to discretion. ${ }^{17}$

While in the deterministic case the Barro and Gordon (1983) model shows the superiority of rules with respect to discretion, in the stochastic case, namely when the expectations-augmented Lucas supply curve is subject to stochastic shocks,

17 This section is based on the formalisation presented in Blanchard (2003). 
such a result does not go through. The intuitive explanation for this result is quite immediate.

In the case of stochastic shocks, the economy is hit by negative perturbations that may cause high unemployment. If these shocks are heavy, 'tying one's hands' implies not being able to respond to them. On the one hand, then, the inflationary bias is avoided, but on the other hand the economy has to stand the cost of a high unemployment. For this reason, following fixed rules will only be optimal if the variability of the shock hitting the economy is not too high.

Let us consider the following simple central bank's loss function:

$$
L_{t}=u_{t}^{2}+\beta \pi_{t}^{2} \quad \beta \geq 0
$$

where $u_{t}$ represents the unemployment rate, $\pi_{t}$ is the inflation rate, and $\beta$ is relative weight assigned to inflation.

Let us minimize it subject to the expectations augmented Phillips curve modified by adding an independent and identically distributed stochastic shock $\varepsilon_{t}$ (in the equation below, $u_{N}$ is the natural rate of unemployment, $\pi_{t}^{e}$ is the expected inflation rate at time $t$, and $\alpha$ is the effect of a surprise inflation on the unemployment rate):

$$
u_{t}=u_{N}-\alpha\left(\pi_{t}-\pi_{t}^{e}\right)+\varepsilon_{t} \quad \alpha \geq 0
$$

More precisely, the stochastic shock $\varepsilon_{t}$ is assumed to be a normally distributed random variable, with zero mean and constant variance: $E\left(\varepsilon_{t}\right)=0$ and $\operatorname{Var}\left(\varepsilon_{t}\right)=\sigma^{2}$.

Substituting (2) into (1), we have:

$$
L_{t}=\left[u_{N}-\alpha\left(\pi_{t}-\pi_{t}^{e}\right)+\varepsilon_{t}\right]^{2}+\beta \pi_{t}^{2}
$$

Let us calculate now the first-order condition to find the value of $\pi_{t}$ that minimizes (3):

$$
\frac{d L_{t}}{d \pi_{t}}=2 \beta \pi_{t}-2 \alpha\left[u_{N}-\alpha\left(-\pi_{t}^{e}+\pi_{t}\right)+\varepsilon_{t}\right]=0
$$

Rearranging Eq. (4) above it follows that:

$$
\pi_{t}=\frac{\alpha}{\beta}\left[u_{N}-\alpha\left(\pi_{t}-\pi_{t}^{e}\right)+\varepsilon_{t}\right]
$$

That is

$$
\pi_{t}=\frac{\alpha}{\beta+\alpha^{2}}\left(u_{N}+\alpha \pi_{t}^{e}+\varepsilon_{t}\right]
$$

To solve the equation above, it is necessary to calculate $\pi_{t}^{e}$. In the case in which economic agents are assumed to take expectations rationally, we have that $\pi_{t}^{e}=E\left(\pi_{t}\right)$.

By applying the operator $E$ to (6), and recalling that $E\left(\varepsilon_{t}\right)=0$, we have that: 


$$
E\left(\pi_{t}\right)=\frac{\alpha}{\beta+\alpha^{2}} u_{N}+\frac{\alpha^{2}}{\beta+\alpha^{2}} E\left(\pi_{t}\right)
$$

namely

$$
E\left(\pi_{t}\right)=\frac{\alpha}{\beta+\alpha^{2}} u_{N}=\pi_{t}^{e}
$$

Let us replace now Eq. (8) into (6), so as to obtain the optimal inflation rate, $\pi_{t}^{D}$ in the discretional case:

$$
\pi_{t}^{D}=\frac{\alpha}{\beta} u_{N}+\frac{\alpha}{\beta+\alpha^{2}} \varepsilon_{t}
$$

It is now possible to calculate the optimal unemployment rate, $u_{t}^{D}$, by replacing the optimal inflation rate calculated above (and the optimal expected inflation rate) in the Phillips curve:

$$
u_{t}^{D}=u_{N}-\alpha\left(\frac{\alpha}{\beta+\alpha^{2}} \varepsilon_{t}\right)+\varepsilon_{t}
$$

namely

$$
u_{t}^{D}=u_{N}+\frac{\beta}{\beta+\alpha^{2}} \varepsilon_{t}
$$

We can now use the optimal values for the inflation rate and the unemployment rate obtained above to calculate the value of the loss function in the discretional case, $L^{D}$ :

$$
\begin{gathered}
L_{t}^{D}=\beta \pi_{t}^{2}+u_{t}^{2}=\frac{\left[\beta \varepsilon_{t}+\left(\alpha^{2}+\beta\right) u_{N}\right]^{2}}{\beta\left(\alpha^{2}+\beta\right)} \\
=\frac{\beta^{2} \varepsilon_{t}^{2}}{\beta\left(\alpha^{2}+\beta\right)}+\frac{2 \beta \varepsilon_{t}\left(\alpha^{2}+\beta\right) u_{N}}{\beta\left(\alpha^{2}+\beta\right)}+\frac{\left(\alpha^{2}+\beta\right)^{2} u_{N}^{2}}{\beta\left(\alpha^{2}+\beta\right)} \\
=\frac{\beta \varepsilon_{t}^{2}}{\left(\alpha^{2}+\beta\right)}+2 \varepsilon_{t} u_{N}+\frac{\left(\alpha^{2}+\beta\right) u_{N}^{2}}{\beta} .
\end{gathered}
$$

Applying the expectation operator $E$ to the above equation and considering that $E\left(\varepsilon_{t}\right)=0$, we obtain:

$$
E\left(L_{t}^{D}\right)=\frac{\beta}{\left(\alpha^{2}+\beta\right)} E\left(\varepsilon_{t}^{2}\right)+\frac{\left(\alpha^{2}+\beta\right)}{\beta} u_{N}^{2} .
$$




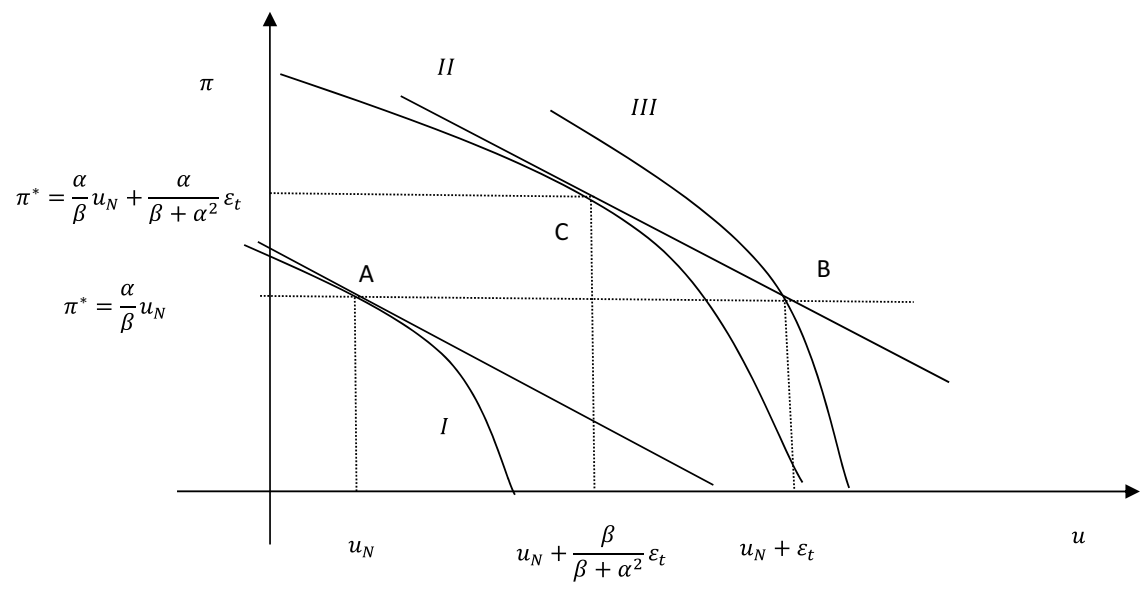

Fig. 1 The effects of a stochastic shock resisted (point C) and not resisted (point B) by the central bank

Considering that we have assumed that $\operatorname{Var}\left(\varepsilon_{t}\right)=\sigma^{2}$, we have that $\operatorname{Var}\left(\varepsilon_{t}\right)=E\left[\varepsilon_{t}-E\left(\varepsilon_{t}\right)\right]^{2}=E\left(\varepsilon_{t}^{2}\right)-E\left(\varepsilon_{t}\right)^{2}=E\left(\varepsilon_{t}^{2}\right)=\sigma^{2}$. The expected loss in the discretional case $E\left(L^{D}\right)$, namely when the central bank makes its own monetary policy decisions to minimize its loss function, then, turns out to be:

$$
E\left(L_{t}^{D}\right)=\frac{\left(\alpha^{2}+\beta\right)}{\beta} u_{N}^{2}+\frac{\beta}{\left(\alpha^{2}+\beta\right)} \sigma^{2}
$$

Now let's calculate the expected loss in the fixed rule case, $E\left(L_{t}^{R}\right)$.

Considering that in such a situation $u_{t}^{R}=u_{N}+\varepsilon_{t}$ and $\pi_{t}^{R}=0$, the value of the loss function is $L_{t}^{R}=\left(u_{N}+\varepsilon_{t}\right)^{2}$, and applying to this equation the operator $E$ we obtain:

$$
E\left(L_{t}^{R}\right)=E\left(u_{N}+\varepsilon_{t}\right)^{2}=u_{N}^{2}+\sigma^{2}
$$

Comparing (13) with (14) we see that, differently from the deterministic case, it is not possible to determine univocally the superiority of 'rules' or of 'discretion'. In fact, while the first term of Eq. (13) is greater than the first term of Eq. (14), the reverse is true for the second term. Intuitively, while the rule solution allows to reduce the inflationary bias that would emerge in the discretionary case, it would not allow to face the effects of a negative shock hitting the economy, thereby resenting a larger loss. Which of the two solutions allows to minimize the expected loss depends on the variance of the shock, as well as on the other parameters of the model. The greater the variance of the shock, the more it will be appropriate not to commit to strict rules.

Vice-versa, following a fixed rule will be the optimal arrangement to make when the variance of the shock is not too high, in which case the benefit deriving from the reduction of the inflationary bias more than compensates the loss resulting from the impossibility to act counter-cyclically. 
The effects of a stochastic shock shifting the Phillips curve can be easily represented by showing that, in the case of a temporary negative shock, maintaining a fixed rule causes a worse outcome than in the discretionary case. Consider, in fact, a situation in which we are in a discretionary equilibrium, such as the one indicated in point A, positioned on an indifference curve of level I in Fig. 1.

A temporary negative shock $\varepsilon_{t}$ will shift the Phillips curve upwards. The intercept will become $\frac{\pi_{t}^{e}+u_{N}+\varepsilon_{t}}{\alpha}>\frac{\pi_{t}^{e}+u_{N}}{\alpha}$. If the central bank keeps the inflation rate unchanged at the level $\pi_{t}^{D}=\frac{\alpha}{\beta} u_{N}$, point $\mathrm{B}$ is reached, at which the unemployment rate will increase to $u_{N}+\varepsilon_{t}$ (positioning the policymaker on the disutility curve of level III). By accepting a slightly higher inflation rate, however, moving from $\mathrm{B}$ to $\mathrm{C}$, it would be possible to reduce the equilibrium unemployment and reach a disutility of level II, thereby lower than the one reached when leaving the shock unabsorbed. Responding to the stochastic shock, then, would allow the optimal inflation rate to be:

$$
\pi^{*}=\frac{\alpha}{\beta} u_{N}+\frac{\alpha}{\beta+\alpha^{2}} \varepsilon_{t}>\frac{\alpha}{\beta} u_{N},
$$

so that the unemployment rate becomes:

$$
u_{t}^{*}=u_{N}+\frac{\beta}{\beta+\alpha^{2}} \varepsilon_{t}<u_{N}+\varepsilon_{t}
$$

It should be clarified that in this model the control variable for the central bank, allowing it to minimize its loss function, is the inflation rate: choosing a given optimal value of $\pi^{*}$, however, would allow not only to minimize the loss resulting from inflation but also the one resulting from the unemployment rate, as determined in the Phillips curve. The implicit assumption of the Barro and Gordon model on which this example is built, of course, is that the inflation rate is controlled by the central bank through the money supply and/or through the interest rate.

\section{References}

Ahir H, Bloom N, Furceri D (2021) What the Continued Global Uncertainty Means for You. IMFBlog, Insights \& Analysis on Economics \& Finance. January 19. In https://blogs.imf.org/2021/01/19/ what-the-continued-global-uncertainty-means-for-you/. Accessed March 2021

Assenza T. et al. (2020) European renaissance bonds to face Europe's health and economic emergency. An open letter of European economists to the Presidents of the EU institutions and to the heads of state and government of the member countries. In https://europeanrenaissance.altervista.org/. Accessed October 2020

Asatryan Z, Havlik A, Heinemann F, Novera J (2020) Biases in fiscal multiplier estimates. Eur J Polit Econ 63:1-25

Baldwin R, Weder di Mauro B (eds) (2020a) Mitigating the COVID crisis: Act fast and do whatever it takes. Vox, CEPR's Policy Porta. In https://voxeu.org/content/mitigating-covid-economic-crisis-actfast-and-do-whatever-it-takes. Accessed October 2020

Baldwin R, Weder di Mauro B (eds) (2020b) Economics in the Time of COVID-19, Vox, CEPR's Policy Porta. In https://voxeu.org/article/economics-time-covid-19-new-ebook. Accessed October 2020

Barro R, Gordon D (1983) Rules, discretion and reputation in a model of monetary policy. J Monet Econ $12: 101-122$ 
Batini N, Callegari G, Melina G (2012) Successful austerity in the United States, Europe and Japan. International Monetary Fund, IMF Working Paper, no. 12/190. In https://www.imf.org/external/ pubs/ft/wp/2012/wp12190.pdf. Accessed May 2015

Becchetti L (2020) Canceling some of the debt in Europe is no longer a taboo. Avvenire.it, 7 December. In http://www.avvenire.it. Accessed January 2021

Becchetti L, Scaramozzino P (2021) COVID-19 debt relief. Scienza e Pace/Science and Peace (forthcoming), 2021

Blanchard O (2003) Macroeconomia. Il Mulino, Bologna.

Blanchard O (2021) Macroeconomics, 8th edn. Pearson, London

Blanchard O, Leigh D (2013, May 3) Fiscal consolidation: At what speed?, Vox, CEPR's Policy Portal. In http://www.voxeu.org/article/fiscal-consolidation-what-speed. Accessed May 2013

Blanchard O, Leigh D (2013) Growth forecast errors and fiscal multipliers. International Monetary Fund. IMF Working Paper, 13/1, January. In https://www.imf.org/external/ pubs/ft/wp/2013/wp1301.pdf. Accessed March 2013

Blanchard O, Pisani-Ferry J (2020) Monetisation: Do not panic. Vox, CEPR's Policy Portal, 10 April. In https://voxeu.org/article/monetisation-do-not-panic. Accessed October 2020

Blyth M (2013) Austerity. Oxford University Press, Oxford. Repr, The history of dangerous idea, p 2015

Boitani A, Perdichizzi S (2018) Public expenditure multipliers in recessions. Evidence from the Eurzone. Department of Economics and Finance, Catholic University of Sacred Heart, Milan. Working paper, no. 68, in http://dipartimenti.unicatt.it/economia-finanza-working-papers-del-dipartimento-n-68public-expenditure-multipliers-in-recessions-evidence-from. Accessed June 2018

CDE.NEWS (2020) EP's President Sassoli Says Joint Borrowing Should Be Made Permanent, 15th November 2020. In https://cde.news/eus-sassoli-says-joint-borrowing-should-be-made-permanent/. Accessed December 2020

Corsetti G, Erce A, Pascual AG (2020) Perpetual bonds are not the best way to finance the European Recovery Fund. In Bénassy-Quéré A, Weder di Mauro B (eds), Europe in the Time of Covid-19. CEPR Press VoxEU.org eBook, London. In https://ideas.repec.org/h/cpr/ ebchap/p328-32.html. Accessed March 2021

Coase R (1960) The problem of social cost. Journal of Law and Economics, 3:1-44. Repr. in Coase (1988)

Coase R (1988) The Firm, the Market and the Law. University of Chicago Press, Chicago, paperback 1990

Coenen G, Straub R, Trabandt M (2012) Gauging the effects of fiscal stimulus packages in the euro Area. European Central Bank Working Paper Series, no. 1483, October, https://www.ecb.europa.eu/pub/ pdf/scpwps/ecbwp1483.pdf?76a5d25d7da74bff801712c488d56079. Accessed December 2012

De Grauwe, P (2020), The European Central Bank must finance COVID-19 deficits, Project Syndicate, March 18, https://www.project-syndicate.org/commentary/ecb-needs-to-embrace-covid19-monet ary-financing-by-paul-de-grauwe-2020-03?barrier=accesspaylog

Deleidi M, Iafrate F, Levrero SE (2020) Public investment fiscal multipliers: an empirical assessment for European countries. Struct Chang Econ Dyn 52:354-365

Della Posta P (2018) L'integrazione monetaria in Europa: origini, crisi, istituzioni e teorie economiche. Pisa University Press, Pisa

Della Posta P (2020) Public debt monetisation and the credibility of the European Central Bank. Social Europe, 28th July. In https://www.socialeurope.eu/public-debt-monetisation-and-the-credibility-ofthe-ecb. Accessed October 2020

Della Posta P, Morroni M (2020) La pandemia disgregherà 1'Unione Europea? MicroMega, no. 3

Della Posta P, Schure P (2020) Italia-Olanda: un confronto fra due economisti. MicroMega, no. 5

Drazen A, Masson P (1994) Credibility of policies versus credibility of policymakers. Quart J Econ 109(3):735-754

Dufrêne N, Scialom L, Couppey-Soubeyran J, Bridonneau B, Giraud G, Lalucq A (2021) Cancel the public debt held by the European Central Bank and take back control of our destiny. In Annuler les dettes publiques détenues par la BCE pour reprendre en main notre destin (annulation-dettepublique-bce.com). Accessed January 2021

Erce A, Pascual AG, Marimon R (2020) The ESM can finance the Covid fight now. Vox, CEPR's Policy Portal. In https://voxeu.org/article/esm-can-finance-covid-fight-now. Accessed October 2020

Galì J (2020) Helicopter money. The time is now. Vox, CEPR's Policy Portal, March 17. In https://voxeu. org/article/helicopter-money-time-now. Accessed April 2020 
Garicano L (2020) Toward a European Reconstruction Fund. Vox, CEPR's Policy Portal. In https:// voxeu.org/article/towards-european-reconstruction-fund. Accessed October 2020

Gaspar V, Medas P, Ralyea J, Ture E (2020) Fiscal Policy for an Unprecedented Crisis. IMFBlog. In https://blogs.imf.org/2020/10/14/fiscal-policy-for-an-unprecedented-crisis/. Accessed October 2020

Giavazzi F, Tabellini G (2020) Covid perpetual eurobonds: jointly guaranteed and supported by the European Central Bank. Vox, CEPR's Policy Portal. In https://voxeu.org/article/covid-perpetual-eurob onds. Accessed October 2020

Guerrieri V, Lorenzoni G, Straub L, Werning I (2020) Macroeconomic Implications of COVID-19: Can Negative Supply Shocks Cause Demand Shortages? NBER Working Paper, no. 26918. In https:// www.nber.org/papers/w26918. Accessed October 2020

International Monetary Fund (IMF) (2012) The Good, the Bad, and the Ugly: 100 Years of Dealing with Public Debt Overhangs. World Economic Outlook: Coping With High Debt And Sluggish Growth. Chap. 3, pp. 101-127. In www.imf.org/external/pubs/ft/ weo/2012/02/pdf/ text.pdf. Accessed November 2012

Kumhof M, Jason A, Bateman W, Lastra RM, Gleeson S, Omarova ST (2020) Central Bank Money: Liability, Asset, or Equity of the Nation? CEPR Discussion Paper, no. DP15521, https://ssrn.com/ abstract $=3753921$. Accessed October 2020

Kydland F, Prescott P (1977) Rules rather than discretion: The inconsistency of optimal plans. J Polit Econ 85:473-491

Marelli E, Signorelli M (2017) Europe and the euro. Integration, crisis and policies. Palgrave Macmillan, Cham

Medema SG (2009) The Hesitant Hand. Taming Self-Interest in the History of Economic Ideas. Princeton University Press, Princeton. Repr. 2011

Morroni M (2018) What Is the Truth About the Great Recession and Increasing Inequality? Dialogues on Disputed Issues and Conflicting Theories. Springer, Cham

Office for Budget Responsibility (2012) Forecast Evaluation report. The Stationary Office, London, October. In http://budgetresponsibility.org.uk/forecast-evaluation-report-october-2012. Accessed May 2015

Reinhart CM, Trebesch C (2016) Sovereign Debt Relief and Its Aftermath, Journal of the European Economic Association, 14:215-251. In https://doi.org/10.1111/jeea.12166. Accessed December 2016

Reuters Staff (2020) European Central Bank's Lagarde says large-scale debt cancellation 'unthinkable'. $9^{\text {th }}$ April. In https://www.reuters.com/article/us-health-coronavirus-ecb-debt-idUSKCN21R0T1. Accessed April 2020

Rodrik D (2017) Rescuing Economics from Neoliberalism. Boston Review, 6th November. In https:// bostonreview.net/class-inequality/dani-rodrik-rescuing-economics-neoliberalism. Accessed December 2017

Soros G (2020) Perpetual bonds could save the European Union. Interview given to De Telegraaf, 22nd May. In www.georgesoros.com/2020/05/22/perpetual-bonds-could-save-the-european-union. Accessed October 2020

Stiglitz JE (1989) On the Economic Role of the State. In Heertje A (ed), The Economic Role of the State. Basil Blackwell, Oxford

Stiglitz J (2020) Priorities for the COVID-19 Economy. Project-Syndicate. In https://www.project-syndi cate.org/commentary/covid-2020-recession-how-to-respond-by-joseph-e-stiglitz-2020-06. Accessed August 2020

Stirati A (2020) Europe's fateful choices for recovery - An Italian perspective. In https://www.inete conomics.org/perspectives/blog/europes-fateful-choices-for-recovery-an-italian-perspective. Accessed October 2020

Svensson L (1993) Fixed Exchange Rates as a Means to Price Stability: What Have We Learned?, Institute for International Economic Studies, Stockholm. In www.diva-portal.org. Accessed January 1994

Publisher's Note Springer Nature remains neutral with regard to jurisdictional claims in published maps and institutional affiliations. 


\section{Authors and Affiliations}

\section{Pompeo Della Posta ${ }^{1} \cdot$ Mario Morroni ${ }^{2}$}

$\triangle$ Mario Morroni

mario.morroni@unipi.it

1 Department of Economics and Management, University of Pisa, Pisa, Italy

2 Department of Political Sciences, University of Pisa, Pisa, Italy 